\title{
CUBA'S ROSWELL CONNECTION: A CRACK IN THE ECONOMIC DOOR?
}

\author{
H. Michael Erisman
}

H. Michael Erisman is professor emeritus of Political Science at Indiana State University in Terre Haute, Indiana. His main fields of interest are US policies toward Latin America, political economy in the Caribbean Basin and Cuban foreign affairs. Relative specifically to Cuba besides numerous articles and book chapters, the most recent of the nine books that he has authored, co-authored, edited, or co-edited is Cuban Foreign Policy: Transformation under Raúl Castro (2018). His current research agenda involves projects dealing with Cuban/ US relations in the area of pharmaceutical collaboration and Cuban medical tourism. He has visited Cuba over 20 times to conduct research, to present papers at conferences and special seminars, and to participate in academic exchanges with Cuban colleagues from the University of Havana and various research centers (e.g. Centro de Estudios Hemisféricos y sobre Estados Unidos and Instituto Superior de Relaciones Internacionales).

For all sad words of tongue and pen,

The saddest are these,

"It might have been".

John Greenleaf Whittier

\section{Introduction}

Whittier's lament about lost opportunities surely can be said to have a certain resonance when it comes to US/Cuban relations, for despite the fact that for over 60 years the dealings between them have often been characterised primarily by suspicion, antagonism and mutual recrimination, there have been occasions when the possibilities for some degree of rapprochement have begun to be explored (LeoGrande and Kornbluth 2015). Often these efforts have been rather low-profile in the sense that they have taken place outside the glare of media publicity and have focused on developing medium-level cooperation on issues of 
pragmatic mutual concern (e.g. combating drug trafficking and promoting orderly migration). These initiatives have not, for the most part, been susceptible to what might be called the "Whittier Syndrome". In other words, the agreements reached have been maintained and long-term cooperation rather than the re-emergence of tensions and animosities has become firmly established.

The same cannot, however, be said for other instances where an inclination among high-level policy-makers to test the waters for a dramatic breakthrough toward a more routine relationship was derailed by a resuscitation, especially in Washington, of the confrontational zero-sum mentality that has long plagued the dealings between the two countries. Three major examples of this dynamic are:

- Despite the fact that the US had been a supporter of the Batista regime, there were some indications in early 1959 of a possible reconciliation between Washington and the new leaders in Havana. On 7 January, just a week after Batista was forced to flee the island, the Eisenhower administration extended diplomatic recognition to the rebel government and one week later replaced ambassador Earl Smith (a political appointee who had been an enthusiastic Batista supporter) with a career State Department diplomat (Philip Bonsal) who had a reputation for being sympathetic toward Latin American reformers. Such civility was, however, rather short-lived. When Castro visited the United States in April 1959, President Eisenhower pointedly refused to meet him by abandoning the White House for a golfing holiday in Georgia. Meanwhile, back in Washington, Castro "did not request any U.S. foreign assistance, which troubled U.S. officials, because they hoped that U.S. aid would be a mechanism for binding Cuba to the United States" (Brenner and Elsner 2018). Things continued to unravel and by the end of the year the CIA began its plans for regime change (which Eisenhower would endorse in March 1960), culminating in the Bay of Pigs fiasco.

- Jimmy Carter assumed the presidency committed to improving relations with Havana (Erisman 2018: 50-2). However, as had been the case with previous administrations, the Carter White House tended at times to interject linkage politics into the picture by demanding that the Cubans make concessions in other policy areas (e.g. loosening their Soviet bloc ties or withdrawing their troops from Angola) as a precondition for better relations, while Havana maintained its long-held position that the rapprochement process must take place within a context of purely bilateral issues. The schism between moderate (i.e. non-linkage) and hardline (i.e. linkage) factions within the administration produced a somewhat complicated schizophrenic approach to addressing the already complex "Cuban question". Initially the moderates, led by such individuals as Secretary of State Cyrus Vance and UN Ambassador 
Andrew Young, carried the day, one result being the opening in September 1977 of "Interest Sections" in each capital staffed by diplomatic and consular officials. ${ }^{1}$ However, in early 1978 the pendulum began to swing in the other direction as a result of Cuba's military involvement in the war which had broken out between Ethiopia and Somalia over the disputed Ogaden region of Ethiopia. The mini-detente between the Carter administration and Cuba became a casualty of the Ogaden war as hardliners led by National Security Adviser Zbigniew Brzezinski increasingly came to dominate US policy toward the island, in the process portraying Havana as totally untrustworthy and irresponsible. This perspective was expressed in such comments as: "This administration has gone damn far to be friendly to Cuba, and we've gotten 12,000 Cubans in the Horn of Africa. We're all very disillusioned about Cuba" (official, 1978). "The Cubans are guns for hire, and they'll go anywhere. They have no compunctions" (official, 1978). This attitude and the hostile policy stance flowing from it were quite comparable with the approach to Cuba of the Reaganites who won the 1980 presidential election.

- Barack Obama was, without a doubt, the American president who made the most dramatic and most conciliatory policy gestures toward Havana, with the three following initiatives generating the most attention in the mass media: 1) he re-established formal diplomatic relations with Cuba; 2) he used his Executive Powers to make it easier for US citizens to travel to the island and for Cuban-Americans to send remittances to their relatives there; and 3) he removed Havana from the State Department's list of governments that support/sponsor terrorism. Moreover, to demonstrate his commitment to improving relations between the two countries, he made a highly publicized official state visit in March 2016, thus becoming the first US president to set foot in Cuba since Calvin Coolidge in 1928.

This thaw in relations would not, however, last very long as the Whittier Syndrome once again came into play with Obama's successor. The Trump administration did not abandon all of Obama's reforms, continuing diplomatic recognition being the most obvious example. But overall Trump reverted to a hard line against Cuba, some examples being: the staff of the US embassy and hence the ability to conduct routine business was reduced to a bare minimum; restrictions on travelling to the island and sending remittances were tightened; and actions were taken to disrupt Havana's ability to import oil,

1 These interest sections served in many respects (except in name) as embassies. They continued to operate until December 2016 when President Obama restored full diplomatic relations with Cuba. 
thus contributing to a major energy crisis for the country. Basically, then, the Trump administration reverted to Washington's traditional stance of trying to enforce sanctions, particularly in the economic sphere, that it hoped would lead to regime change in Havana and thereby a reassertion of US hegemony over the island.

With respect to the Obama opening, the spotlight focused primarily on the resumption of diplomatic ties. What went almost unnoticed, however, was the fact that his rapprochement produced some significant advances in economic relations between the two countries. In particular, Obama began to interject an important element that had heretofore been missing from the equation - reciprocity with respect to the sale of goods and services. Previously any deviation from Washington's trade restrictions involved one-way transactions that allowed US entities such as agricultural companies to make export sales to Cuba, but generally did not provide similar opportunities for the importation of Cuban goods into the United States. One could not, for example, find Cuban cigars or rum on the shelves of US stores. The Obama administration, however, would take the first significant step toward opening this previously closed door.

The first and admittedly rather modest gesture that the Obama administration made in this direction occurred in December 2014 when it was announced that products of privately run or cooperative farms (but not state owned/ operated) in Cuba could now be exported to the United States, the basic idea being to support the development of the private sector in the country's economy. The first US company to take advantage of this initiative was Fogo Premium Lump Charcoal of Florida which in early January 2017 announced that it had purchased 40 tons of charcoal (total price $=\$ 16,800$ ) which is produced by hundreds of worker-owned cooperatives across the island (Weissenstein 2017). Later, in July 2018, Fogo bought another 40 tons (Cuba Trade 2018). A second US company, Gulfwise Commerce of Alabama, closed a similar charcoal deal for approximately \$14,000 in May 2019 (Gulfwise 2019). As of early 2021, the only other transaction under these revised stipulations involved Nespresso, a subsidiary of the Swiss-based Nestlé Corporation, which announced in June 2016 that it would begin to sell Cuban-grown arabica coffee in the United States (Baertlein and Nicholson 2016). While significant in a symbolic sense, all of the foregoing relationships involve specialty products with a limited capability to make major contributions to the Cuban economy. Certainly none have the growth and income potential of the pharmaceutical sector where Roswell has taken the lead in establishing a Havana connection.

As is usually the case as a result of the sanctions that Washington has imposed on relations with the island, very few Americans are aware of developments in Cuba. Certainly one of the major untold stories is the fact that the island's 
medical community has made remarkable strides in pharmaceutical research and development, operating at a world-class level. The scope of these activities (circa 2018) can be briefly summarised as follows (Evans et al. 2018: 26):

Cuba started biotech research and production as early as 1982. . . Cuba's Center for Biological Research, producing both natural and recombinant interferons, opened in January 1982. ... Today, Cuba's globally recognized BioCubaFarma Enterprise Group consists of 31 enterprises and 8 commercial companies with over 20,000 employees and 62 manufacturing facilities.

CIM [with whom Roswell would affiliate] was founded in Havana in January 1991 and its present venue inaugurated in 1994. ... CIM now operates four manufacturing facilities and has over1100 employees. It exports products to over 30 countries and has filed 750 patents abroad, including in the USA.

Such information has not, however, escaped the attention of Cuba's US counterparts where both high-profile industry leaders such as Pfizer and Lilley as well as smaller companies have long been well aware of and highly interested in the island's accomplishments. It was, therefore, in this sector that the Obama administration decided to make its main move by relaxing restrictions on collaborative clinical trials that could eventually open the highly lucrative domestic market to Cuban-developed drugs. The first US institution to take advantage of this opportunity was the Roswell Park Cancer Institute of Buffalo, New York, which has, as we shall see, taken steps not only to develop a research relationship with its Cuban partners, but likewise a commercial one. Adding a surprising dimension to this scenario is the fact that the Trump administration, despite its hardline anti-Cuban rhetoric and its very real efforts to roll back Obama's gestures toward reconciliation and (as noted above) tighten US sanctions against Havana, did not move to reseal the reciprocity door by dismantling the Cuba/Roswell connection.

Given this unique and in many respects unprecedented situation in the long, contentious saga of Washington's policies toward revolutionary Cuba, the following material will:

1. Explain the key provisions of the US sanctions regime against Cuba which focus on import trade provisions in general and those elements thereof relating specifically to the medical/pharmaceutical sector.

2. Summarise the development of the Cuban/Roswell collaboration.

3. Explore the political (as opposed to the highly technical medical and professional medical) dynamics behind the establishment and to this point the maintenance of this relationship. 


\section{US Import Trade Sanctions and Health-Related Transactions}

Of all of Washington's active sanctions programmes, Cuba holds the dubious distinction for longevity. The first measures were imposed in early 1962 by the Kennedy administration and since then have grown into an extremely complex (and potentially confusing) mixture involving such elements as congressional legislation, presidential executive orders and bureaucratic regulations. ${ }^{2}$ The most comprehensive compendium can be found in the Code of Federal Regulations, Title 31, Section 515, where, with respect to the question of importing Cuban goods, the general principle is laid down that:

Except as specifically authorized by the Secretary of the Treasury (or any person, agency, or instrumentality designated by him) by means of regulations, rulings, instructions, licenses, or otherwise [emphasis added], no person subject to the jurisdiction of the United States may purchase, transport, import, or otherwise deal in or engage in any transaction with respect to any merchandise outside the United States if such merchandise: (1) Is of Cuban origin; or (3) Is made or derived in whole or in part of any article which is the growth, produce or manufacture of Cuba (OFAC, 2011).

Here subsections (1) and (3) would seem to suggest that no imports into the US from Cuba are allowed and indeed for many years such was essentially the case, especially with regard to basic commercial products. However, the emphasised material above provides for exceptions to this general rule. Such exceptions are for the most part obtained via one of the two following mechanisms: 1) applying for and receiving a "specific license" from OFAC (Office of Foreign Assets Control, Treasury Department) to undertake a particular activity; or 2) falling into one of the OFAC categories of approved activities which then constitutes a "general license" to proceed. ${ }^{3}$

In the waning days of the Obama administration, the departments of Treasury and Commerce, acting under the auspices of the President's policy directive

2 As of 2018, the Cuban embargo is enforced mainly through six statutes: the Trading with the Enemy Act of 1917, the Foreign Assistance Act of 1961, the Cuban Assets Control Regulations of 1963, the Cuban Democracy Act of 1992, the Helms-Burton Act of 1996 and the Trade Sanctions Reform and Export Enhancement Act of 2000.

3 For example, at one time university faculty members had to apply for a specific license to travel to Cuba to undertake professional activities. Later a change was made which now covers such activities under a general license, so an application is no longer necessary. 
seeking to promote better relations with the island, announced some major changes on 14 October 2016 affecting health-sector transactions between the two countries. The following, found in section 515.547 of the Cuban Assets Control Regulations (OFAC), were the most dramatic:

(a) Persons subject to U.S. jurisdiction are authorized to engage in all transactions incident to joint medical research projects with Cuban nationals.

Note 3 to paragraph (a): This paragraph also does not authorize persons subject to U.S. jurisdiction to establish a business or physical presence in Cuba, to hire Cuban nationals, or to engage in any transactions prohibited by $\$ 515.208 .^{4}$

(b) Persons subject to U.S. jurisdiction are authorized to engage in all transactions incident to obtaining approval from the U.S. Food and Drug Administration (FDA) of Cuban-origin pharmaceuticals, including discovery and development, pre-clinical research, clinical research, regulatory review, regulatory approval and licensing, regulatory post-market activities, and the importation into the United States of Cuban-origin pharmaceuticals.

(c) Persons subject to U.S. jurisdiction are authorized to engage in all transactions incident to the marketing, sale, or other distribution in the United States of FDA-approved Cuban-origin pharmaceuticals, including the importation into the United States of Cuban-origin pharmaceuticals. (OFAC 2016)

Essentially, what these three provisions provide is a general license for activities that previously required specific licenses. The two initial provisions focus essentially on promoting research collaboration which could culminate in FDA approval of the drug under consideration. Item (c), on the other hand, goes to the heart of the trade reciprocity question, for it appears to clearly authorise the sale in the American market of pharmaceuticals developed via the a/b collaboration and manufactured in either the US and/or Cuba. However, Note 3 attached to paragraph (a) would appear under some circumstances to preclude US citizens from becoming involved in any such manufacturing operations that are located in Cuba (an option that Roswell will ultimately explore since Note 3 will not be applicable to its collaborative agreements).

4 Section 515.208 reads as follows: No United States national, permanent resident alien, or United States agency may knowingly make a loan, extend credit or provide other financing for the purpose of financing transactions involving confiscated property the claim to which is owned by a United States national, except for financing by a United States national owning such a claim for a transaction permitted under United States law. 


\section{The Development of the Cuban/Roswell Connection}

The Cuban/Roswell connection (see Appendix for timeline) began in 2011 when a researcher from the Centro de Inmunología Molecular (CIM) in Havana who was visiting relatives in the United States contacted Roswell asking if they would be interested (which they were) in having her visit and give a presentation regarding CIM's work in the area of cancer vaccines. Thus Roswell's scientists got their first detailed briefing about CIMAvax-EGF, an immunotherapy developed at CIM as a treatment for lung cancer. It would appear that this event played a major role in laying the foundation for what would develop into a remarkable groundbreaking collaboration which would have the potential to open the door, despite Washington's long-standing commitment to a policy of economic/trade sanctions on the island, to the US market for Cuban pharmaceuticals.

This initial contact having set the collaborative wheels in motion, Roswell (as it could do under existing regulations) applied for and in 2013 received an OFAC specific license permitting it to conduct clinical trials in the US of two CIM cancer vaccines and three of its immunomodulatory drugs. Shortly thereafter each of the two parties - Roswell and CIM - began to work on proposed clinical testing protocols and legal agreements that were necessary in order to establish a formal collaborative relationship (Evans et al. 2018). These efforts bore fruit two years later (April 2015) when CEO Candace Johnson led a Roswell delegation that accompanied New York Governor Andrew Cuomo on his state trading mission to Cuba. At the conclusion of the visit, a formal agreement was signed establishing a collaborative research partnership (beginning with CIMAvax) between Roswell Park and CIM. Ms Johnson, clearly aware of the groundbreaking significance of the event, commented that "It was precedentsetting to say the least. ... When we first came back from Cuba from that trade mission, the world was abuzz because at that time really no one was going to Cuba" (Buffalo News 2020).

In terms of developing the Cuban/Roswell connection, 2016 was a particularly active and challenging year, especially as the Obama reforms came into play. To help in navigating the US regulatory labyrinth, Roswell hired a high-powered lobbying firm - Akin Gump Strauss Hauer \& Held LLP - at more than \$200,000 per year. This initiative appeared to pay substantial dividends when Roswell acquired a specific OFAC license in 2016 to create a joint venture company with the Cuban government that would employ both US and Cuban citizens to, among other things, manufacture drugs developed via their collaborative research (Cuba Standard 2018) for export to various destinations, including the US. The site selected for this groundbreaking joint venture is the Mariel Special Development Zone, a 115,000-acre facility west of Havana where Cuba is trying to attract 
foreign companies. The joint venture partners are CIM's commercial affiliate CIMAB and a Roswell Park subsidiary called GBCT II, with each company having equal roles in oversight of the operation (called the Innovative Immunotherapy Alliance) (Miami Herald 2018). Roswell's CEO Candace Johnson summarised these developments as follows: "This is a momentous step forward on one of our most significant undertakings. With the establishment of this company, we are entering a critical new phase of Roswell Park's collaboration with these innovative Cuban scientists" (Cuba Standard 2018).

However, with the advent of the Trump administration, the future of this Roswell/Cuban joint venture in Mariel became somewhat clouded as the White House in June 2017 announced new restrictions on economic relations with Cuba. On the one hand, the administration now declared that:

(a) no person subject to U.S. jurisdiction may engage in a direct financial transaction with any person that the Secretary of State has identified as an entity or subentity that is under the control of, or acts for or on behalf of, the Cuban military, intelligence, or security services or personnel and with which direct financial transactions would disproportionately benefit such services or personnel at the expense of the Cuban people or private enterprise in Cuba. (OFAC 2017)

The above provisions represented a tightening of US trade sanctions since Havana's armed forces personnel (both active and retired) are involved in one way or another with the operation of various sectors of the island's economy. ${ }^{5}$ In particular, the Mariel Special Development Zone is on the restricted list of entities off limits for American companies because of its ties to the Cuban military, which would suggest that the Roswell joint venture enterprise involving commercial/manufacturing activities is prohibited under US law. There is, however, an apparent "escape clause" in the Trump regulations which states that:

5 It has been widely reported that approximately 60 percent of Cuba's economy is under control of the military. This estimate is, however, grossly exaggerated according to William LeoGrande, who characterises it as "ludicrous". His research shows that while current and retired military personnel have a significant role in, for example, the island's tourism sector, their overall presence in the economy is nowhere near 60 percent. He concludes that the more accurate figures regarding the revenue from their activities would be " $21 \%$ of total hard currency income from both state enterprises and the private sector, $8 \%$ of total state revenue, and just $4 \%$ of GDP... . That's a long way from $60 \%$ of the economy, no matter what metric you use" (LeoGrande, 2017). 
(c) The prohibition in paragraph (a) of this section [above] does not apply to any transactions related to commercial engagements that involve direct financial transactions with an entity or subentity on the Cuba Restricted List, provided those commercial engagements were in place prior to the date that entity or subentity was added to the Cuba Restricted List as published in the Federal Register. (OFAC 2017)

So what was the status of Roswell's Cuban connections as the Trump administration came to an end and Joe Biden moved into the Oval Office? In a nutshell, they were "safe" because: (1) Obama's OFAC provisions regarding medical research collaboration and related activities (see section 515.547 material above) were not rescinded by the Trump White House; and (2) Roswell's collaborative agreements undertaken pursuant to the Obama provisions either do not entail engagement with the Cuban armed forces or, as is the case with the Mariel joint venture, are covered by Trump's “grandfather clause - section (c) above - since they were in place prior to Trump's presidency.

Moreover, changes or additions to the OFAC sanctions regulations such as those implemented by both Obama and Trump are based on the executive powers of the President. As such, executive orders issued during one administration can be nullified by one of its successors. Biden entered the White House in January 2021 committed to exercising just such authority in order both to nullify various executive actions taken by Trump and to implement some of his own priorities in various policy areas, including Cuba. It was, however, unclear as the Biden team swung into action as how far the new president was willing to go in terms of improving relations with Havana. Certainly the initial indications were that he would move very cautiously and very modestly. Reuters, for example, reported in late February 2021 that the Biden administration appeared to have little sense of urgency for major gestures toward Cuba despite hopes for a softer approach after Trump, basing this conclusion on comments by a White House official, speaking on condition of anonymity, that

a Cuba policy shift was not currently among Biden's top priorities, which include the coronavirus pandemic, economic recovery and rebuilding alliances abroad. "Frankly, first things first," the official said. There has also been no sign of any immediate plans to rescind Cuba's designation as a state sponsor of terrorism, though Biden officials have said Trump's last-minute decision to return Havana to the U.S. blacklist is under review. (Spetalnick 2021)

Also, the Trump administration's restrictions/prohibitions upon transactions with entities controlled by the Revolutionary Armed Forces (FAR) of the Republic of 
Cuba were expected to remain in place (Cuba Trade 2021). Finally, there were no signs that Biden was planning any dramatic initiatives in reciprocal trade relations between the two countries. As such, it appeared that the Roswell connection would remain as Cuba's premier potential gateway for exports into the American market.

\section{The Political Dynamics of the Roswell/Cuba Connection}

Most of the news reports and other commentary on the Roswell/Cuba connection, which in fact have been quite limited, have concentrated on the medical aspects of the evolving relationship. ${ }^{6}$ There have, for example, been very detailed technical discussions of the drugs involved and the clinical procedures by which they can receive FDA approval. But Cuba has long been and continues to be a highly politicised issue in the US and especially in Washington. As such, political considerations almost inevitably become a key element affecting the outcome of any matter that has the potential to affect the bilateral relationship. Certainly the Roswell/Cuba connection falls into that category, yet the political dynamics as well as some other key factors involved in its development have received little, if any, attention. Questions such as the following have not been addressed in any significant way:

- Why did Obama choose to focus on the pharmaceutical sector when opening the reciprocity door?

- Specifically, why did Roswell emerge as the US partner in this venture?

- Perhaps most intriguing, why didn't the Trump administration, given its commitment to tightening US sanctions, take action to dismantle these Obama reforms?

Providing answers is not an easy task since much of the dynamics involved has played out behind closed doors, but we will try here to take some first steps in doing so.

With respect to the first item in this list, one certainly has to wonder "Why pharmaceuticals?" Normally it takes eight to ten years of clinical trials before the FDA approves a drug for distribution in the US. This being the case, and assuming that the Obama administration wanted to fast-track an import

6 Some material in this section is based on interviews with Dr William LeoGrande (American University, Washington, DC, interviewed 2 December 2020) and Dr Raúl Rodríguez (Director, Center for Hemispheric and US Studies, Havana, interviewed 10 February 2021). 
relationship with Cuba, why not do so with respect to such products as nickel, rum, cigars and the like where the island's exports could begin to flow into the American market almost immediately?

Viewed from a purely economic perspective, the pharmaceutical play seems to provide the greatest opportunity for American companies to get a piece of the action because, as opposed to most other product options, approval by a US government agency (i.e. the FDA) involving a very complicated and demanding procedure is absolutely necessary in order for a Cuban-related drug to be able to access the very lucrative American market. Therefore a joint venture approach with a US partner would seem to make the most sense from a Cuban perspective. Moreover, because the gross sales and profit margins usually are extremely high in the US pharma sector, Havana is likely to be more willing to take on US partners than might be the case with such items as rum or cigars where there is likely to be much less money involved and hence much less willingness to share the proceeds with a foreign company.

But beyond the mutual economic benefits involved in focusing on the pharmaceutical sector, there are also various political considerations that come to mind which Obama and his supporters probably saw as major factors working in both the short- and long-term favour of his reforms:

- First, the big US pharma companies, which have already demonstrated an interest in Cuba's R\&D achievements (especially in the biotechnological field), would almost certainly mobilise as strong political allies in support of this initiative. An example of such interest can be seen with respect to Governor Cuomo's 2015 trip to Cuba. As noted previously, Roswell's CEO was a member of that delegation and signed a formal agreement for collaborative research with Cuba's CIM centre. But also on hand were representatives from Pfizer, one of the world's largest pharmaceutical firms (headquartered in New York City) who, it can be assumed, were scouting the territory for potential future research/commercial opportunities.

- Second, supporters of this initiative would be able to frame it in humanitarian terms of the potential benefits regarding the health and well-being of American citizens, therefore forcing opponents into the uncomfortable political (and electoral) position of appearing to be the opponents thereof. Indeed the humanitarian rationale for a Cuban connection goes far beyond the ravages wreaked on US society by cancer. For example, Cuban researchers have also been heavily involved in attempting to confront the scourge of Alzheimer's disease, announcing some success in exploring both modern drug and traditional medicine approaches (Gonzalez Alayón 2017; Granma 2017). 
- Lastly, the fact it would take eight to ten years for the first Cuban-related drugs to be ready to be imported would be seen as not only giving supporters of the initiative plenty of time to prepare groundwork for this eventuality, but also would allow them to do so in a low-profile manner that would remove the issue from the highly impassioned controversy and histrionics that often emerges when a "Cuban question" is raised in the domestic political arena.

On the Cuban side of the "choice equation" it would certainly seem at first glance somewhat surprising that Havana decided to align with Roswell as its partner in this groundbreaking initiative to interject a significant element of commercial reciprocity into what had heretofore essentially been an unequal trade relationship wherein the US market was closed to Cuba. Instead, one might reasonably have expected Havana to be inclined to opt for a partner who could bring more political as well as financial/ commercial resources to the table. Consider, for example, a "heavyweight" such as Pfizer, which as noted has made some effort to establish contacts within the Cuban pharmaceutical community. The table provides a brief comparison of Roswell and Pfizer in terms of their financial and human resources.

Table 1 Comparative Resources: Roswell and Pfizer

\begin{tabular}{lll}
\hline & Roswell & Pfizer \\
\hline Sales Revenue (2020) & $\$ 846.7$ million & $\$ 41.908$ billion \\
Employees (2020) & 3,300 & 88,300 \\
\hline
\end{tabular}

Sources: https://www.owler.com/company/roswellpark; https://www.google.com/search?client=firefoxb-d\&q=pfizer+sales+revenue+2020; https:/www.google.com/search?client=firefox-b$\mathrm{d} \& \mathrm{q}=$ pfizer+employees +2020

In the final analysis, it is, of course, possible that Pfizer and perhaps similar US large pharma companies have for whatever reasons been unwilling to this point to enter into partnerships with Cuba. On the other hand, however, there are some possible reasons why Havana may indeed have preferred Roswell. For example,

- Prior to any expressions of interest from third parties (such as Pfizer), CIM very well may have already established a connection with and confidence in Roswell based on interactions occurring at professional conferences between researchers from both institutions. Evidence supporting this hypothesis can be drawn from the CIM visit to Roswell in 2011. It is very unlikely that this was a "spur of the moment" individual gesture on the part of the CIM 
researcher, but rather was an initiative authorised both by CIM's leadership and the Cuban government based on an existing relationship. Quite simply, then, this suggests that Roswell was "first in line" and that Havana was inclined to go with a known quantity rather than waiting for other options which might not have developed.

- Susan Johnson, Roswell's CEO, provided a more interpersonal analysis in a PBS documentary as to why Cuba chose to partner with Roswell instead of cancer centres that are bigger, more famous or have more money, stating (Pergament 2020) that: "You've got to look Cubans in the eye. They have to know you to trust you. And I think part of the reason we were successful is ... we developed a trust between our two institutions even though ... the politics between our two countries is very tense and sometimes controversial." Given the long history of acrimony that Havana has confronted in its relations with Washington, it should not be surprising that developing such trust is almost always a prerequisite for US private citizens seeking a cooperative relationship with their Cuban counterparts. Certainly, Johnson seemed to feel that Roswell's success in doing so was a major consideration in establishing it as a viable competitor to other larger firms.

- It is also possible that the Cubans were leery of affiliating with one of the very large firms because they feared that they would be relegated to a very junior partner status within such a context. In other words, they may have been concerned that they would be at a serious disadvantage with respect to bargaining power if dealing with one of the major companies and that their concerns might therefore be accorded a rather low ranking within their partner's list of priorities.

Finally there is, perhaps, is no more intriguing issue concerning the dynamics at play in the development of the Roswell/Cuban connection than what was apparently the Trump administration's total disinterest in doing anything about it. Certainly it is no exaggeration to suggest that Trump, whether for personal, political and/or ideological reasons, was as president a gold star member of that faction within the US body politic committed at a minimum to making life as miserable as possible for the Cuban Revolution and ideally to destroying it. As such, just as Obama had used his executive powers to institute an impressive list of reforms designed to improve relations with Havana, so also Trump used his to roll back many of those initiatives and to impose more draconian restrictions on the island (especially in the realm of economic affairs). Surprisingly, however, no attention was paid to nor was there any effort on the part of the Trump administration to quash the changes in OFAC regulations which Obama made concerning the pharmaceutical sector and which thereby reversed the long-held anti-reciprocity 
principle that denied Cuban products access to the US market. Roswell, as we have seen, was able to take advantage of this situation and establish the first research/commercial partnership with a Cuban pharmaceutical enterprise.

At first glance the Trump administration's passivity with respect to this issue appears rather perplexing, especially since Trump had stressed both during and after the presidential campaign his firm commitment to "get tough" with Cuba. Several possibilities by leading experts on US/Cuban affairs have, however, been proposed to explain this paradox.

William LeoGrande, whose base in Washington gives him an ideal platform from which to comment on the American political scene, reports that he was not aware of any major controversy concerning the developments surveyed here (i.e. the pharma/reciprocity reforms and the Roswell connection) between supporters and opponents of more normalised relations with Cuba during either the Obama or Trump administrations. This can be attributed, he suggests, to such considerations as:

- The fact that during the 2015-16 period Obama had so many other reforms on the table that the Roswell/pharma issue simply did not attract any attention. In short, because the Obama administration was coming up with a new package of Cuba proposals (four or five) every few months or so, the Roswell connection and associated policy initiatives flew under the radar.

- Trump was primarily interested in (if not obsessed with) cutting off current flows of hard currency to Havana via such mechanisms as restricting/ disrupting travel, remittances, foreign investment and revenue from medical assistance programmes. The Roswell/pharma scenario, given the long developmental processes involved, does not fall neatly into this category of concerns and hence received no attention of any significance from his administration.

Raúl Rodríguez, operating out of Havana, supports LeoGrande's second point by stating in an interview that:

Trump administration policy concentrated on short term goals, its efforts being geared toward bankrupting the Cuban state by attacking Havana's main sources of foreign revenue, especially the export of professional services (mainly medical) and tourism/travel as well as concentrating on such vulnerabilities as the island's dependence on oil imports (which led Washington to try to stop oil from Venezuela and elsewhere from getting to Cuba) and its need to attract foreign investment. All of these initiatives were to one degree or another designed to contribute to regime change in Cuba, a characteristic which had the added 
domestic political advantage of appealing to the deep currents of ideological confrontationalism with Havana found in the Trump base in general and especially among the right wing Cuban-Americans in Florida (a key state in US Congressional and presidential elections).

He then goes on to point out that there are existing agreements with Cuba that are important and beneficial to the US. Examples of these agreements can be found in such pragmatic issue areas as security, coast guard operations, orderly Cuban immigration and law enforcement cooperation in combating problems like the drug trade and other areas of international criminal activity. These agreements are mutually beneficial and therefore have for the most part been scrupulously respected by both governments.

So, he concludes, it is not particularly surprising that the Trump administration would not be inclined to concern itself with or to expend any significant political capital on an agreement (the Roswell connection) regarding cancer research (flowing from Obama's reforms) that would not produce any major short-term results and if anything would be beneficial to the US. Thus, essentially by default, the Roswell/Cuban connection was ignored and thereby allowed to move forward.

\section{Conclusion}

Clearly Obama's reforms with respect to cooperation with Cuba in the area of pharmaceuticals and the Roswell connection flowing from them represented a major and in many respects an unprecedented action on Washington's part to moderate its traditional hardline sanctions policy by interjecting an element of reciprocity into the economic relationship which has the potential to provide Havana with a robust stream of vital hard currency (i.e. US dollars).

Moreover, such initiatives could very well serve as catalysts for similar moves in other economic/trade sectors by contributing to what is known as “confidence-building” measures. James Macintosh summarises this concept as follows (1996: 45):

Confidence building, according to the transformation view, is a distinct activity undertaken by policy makers with the minimum intention of improving some aspects of a traditionally antagonistic... relationship through...policy coordination and cooperation. It entails the comprehensive process of exploring, negotiating, and then implementing tailored measures, including those that promote interaction, information exchange, and constraint. It also entails the development and use of both formal and informal practices and principles associated with the cooperative development of CBMs [Confidence Building 
Measures]. When conditions are supportive, the confidence building process can facilitate, focus, synchronize, amplify, and generally structure the potential for a significant positive transformation in the relations of participating states.

In other words, confidence-building measures can generate a long-term spillover effect into other (broader) areas resulting in a dramatic transformation in the relations between two countries, which in the case of the US and Cuba could lead to further or perhaps even complete abandonment by Washington of its sanctions against the island.

At this point, however (April 2021), it would appear that the above perspective has to be considered overly optimistic since the Whittier syndrome seems once again to be at work. But in this case, as opposed to instances such as those noted above, it is other American pharma companies rather than the US government that have fallen prey to it. Washington, as we have seen, has not rolled back the Obama reforms, even during virulently anti-Cuban Trump administration. Nevertheless, except for Roswell, there is little indication that other US pharmaceutical firms have made any serious efforts to take advantage of the opportunities available for research/commercial collaboration with Cuba. Why they are exhibiting such reluctance is puzzling, especially since the Cuban research community has demonstrated an impressive scope in terms of its activities and research agendas. ${ }^{7}$ Our focus here, of course, has been on CIM's accomplishments in the battle against cancer, but it and other centres have also made significant strides in developing vaccines and other medications/treatments in a wide range of high-profile and challenging areas (some examples being meningitis, COVID-19, Alzheimer's, diabetic foot ulcers, dengue and hepatitis B). In short, there are a lot of potential areas for mutually beneficial collaboration in both a humanitarian and a scientific sense (as well as from a profit-motive standpoint).

Given that the basic Obama reforms with respect to pharma R\&D collaboration with Cuba are still on the books, there are two things Biden administration could do to "jump-start" broader participation in the R\&D process:

1. Remove Cuba from the US list of countries involved in and/or supporting terrorist activities.

2. Remove the ban on doing business with Cuban pharmaceutical operations that may be affiliated with the Cuban military (such as joint venture activities in the Mariel Special Development Zone).

7 A detailed profile of the Cuban healthcare/medical research system can be found in Rojo Pérez 2018. 
These provisions were implemented during the Trump administration utilising the presidential power of executive orders. In both cases their economic goal has been to minimise, if not eliminate, the opportunities for any US individual or organisation (e.g. pharma companies) to engage in any activities that might benefit the Cuban economy. For example: being put on the US terror list exposes countries to a suite of sanctions, including "restrictions on U.S. foreign assistance; a ban on defense exports and sales; certain controls over exports of dual use items; and miscellaneous financial and other restrictions" (Chappell, 2021). The ultimate hope is, of course, that such pressure will contribute to regime change and the disintegration of the Revolution.

Roswell, as we have seen, appears for the most part to have escaped these restrictions because it finalised its relationship with CIM before they were imposed. Hence its connection has in effect been "grandfathered". But other US pharmaceutical companies are subject to them. President Biden (and his successors?) can, as did Trump, wield his executive powers not only to nullify the above sanctions, but also to expand the opportunities for US/Cuban cooperation with respect to the pharmaceutical/health sector in particular and ideally beyond into a broad range of activities. Hopefully he will do so, but that remains to be seen.

\section{APPENDIX}

\section{Timeline: Key Points in the Development of the Roswell/Cuban Connection}

2011: Cuban researcher from CIM visits Roswell and gives a presentation regarding CIM's work in cancer research. A key event in the development of the Roswell/Cuban connection.

2013: Roswell receives an OFAC license to permitting it to conduct clinical trials in the US of two CIM cancer vaccines and three immunomodulatory drugs.

2015: April. Roswell CEO goes to Cuba as member of a trade mission led by New York Governor Andrew Cuomo and signs an agreement establishing a formal collaborative research partnership with CIM.

2016: September. Roswell receives an OFAC license to create a joint venture company with the Cuban government to manufacture and export drugs developed via their research collaboration.

2018: September. Joint venture company created with the Mariel Special Development Zone in Cuba selected as the headquarters site for the company's manufacturing and export activities. 
2020: November. Joseph Biden elected President of the US Indicates an intention to return to a Cuban agenda modelled along the lines of the Obama administration's policies.

2021: January. Biden assumes the presidency, but does not appear inclined to take any dramatic initiatives to improve relations with Havana.

\section{References}

Baertlein, Lisa, and Nicholson, Marcy (2016) "Cuban coffee returning to U.S. but only fopr Nespresso brewers". Available at: https://www.reuters. com/article/us-cuba-coffee-nestle-idUSKCN0Z61E3 (accessed 20 April 2021).

Brenner, Philip, and Eisner, Peter (2018) Cuba Libre: A 500-Year Quest for Independence. Lanham, MD: Lexington Books.

Buffalo News (2020) "Roswell Park's alliance with Cuba gets the 'wow' treatment from PBS’ Nova”. Available at: https://buffalonews.com/ opinion/columnists/roswell-parksalliance-with-cuba-gets-the-wow-treatment-from-pbs-nova/article_5f70faea-6d185a7b-bbfa-8b43ac4dd158.html (accessed 21 April 2021).

Chappell, Bill (2021) "U.S. puts Cuba back on list of state sponsors of terrorism". Available at: https://www.npr.org/2021/01/11/955641839/ u-s-puts-cuba-back-onlist-of-state-sponsors-of-terrorism (accessed 20 April 2021).

Cuba Standard (2018) “U.S. research institution creates biotech joint venture at Mariel". Available at: https://www.cubastandard.com/u-s-research-institution-creates-biotechjoint-venture-at-mariel/ (accessed 21 April 2021).

Cuba Trade (2018) "Fogo in Florida confirms 2nd charcoal purchase from Cuba: teo $20 \mathrm{ft}$ containers”, U.S.-Cuba Trade and Economic Council. Available at: https://www.cubatrade.org/blog/2018/10/23/fogo-in-florida-reports-2nd-charcoal-purchase-from-cubatwo-20ft-containers (accessed 21 April 2021).

Cuba Trade (2021) "On 20 January 2021, this skilled politician will be the most important member of Congress for issues relating to Cuba”. Available at: https://www. cubatrade.org/blog/2021/1/9/43fecv3m5xmrc1my48nas0kuzzrwa6 [Accessed 21 April 2021].

Erisman, H. Michael (2018) "David rising: Cuba and its northern Goliath in the 1970s”, in Emily J. Kirk; Anna Clayfield and Isabel M. Story (eds), Cuba's Forgotten Decade: How the 1970s Shaped the Revolution. Lanham, MD: Lexington Books, 41-54.

Evans, Rachel, Reid, Mary, Segal, Brahm, Abrams, Scott I., and Lee, Kelvin (2018) "Case study in international cooperation: Cuba's Molecular Immunology Center and Roswell Park Cancer Institute”, Mediccreview. Available at: http://mediccreview.org/ case-study-in-international-cooperation-cubas-molecular-immunology-center-androswell-park-cancer-institute/ (accessed 25 June 2021).

González Alayón, Abel (2021) "Cuba to create a food against Alzheimer's disease”. Available at: http://www. cubanews.acn.cu/science/12915-cuba-to-create-a-foodagainst-alzheimer-s-disease (accessed 20 April 2021). 
Granma (2017) “Cuba develops medicine to combat Alzheimers”. Available at: http:// en.granma.cu/cuba/2017-05-16/cuba-develops-medicine-to-combat-alzheimers (accessed 20 April 2021).

Gulfwise (2019) “Gulfwise Commerce inks deal to purchase Cubn artisanal 'Marabu' charcoal”, Gulfwise Commerce. Available at: http:/gulfwisecommerce.com/ news (accessed 20 April 2021).

LeoGrande, William (2017) “Analysis: does the Cuban -military really control $60 \%$ of the economy?”. Available at: https://www.huffpost.com/entry/does-the-cuban-militaryreally-control-sixty-percent_b_59530b0ee4b0f078efd985d8 (accessed 28 June 2021).

LeoGrande, William, and Kornbluth, Peter (2015) The Hidden History of Negotiations between Washington and Havana. Chapel Hill, NC: University of North Carolina Press.

Macintosh, James (1996) Confidence Building in the Arms Control Process: A Transformation View. Ottawa: Arms Control and Disarmament Studies, Department of Foreign Affairs and International Trade.

Miami Herald (2018) "Goal of first U.S.-Cuba biotech joint venture is to export Cuban cancer drugs to U.S.” Available at: https://www.miamiherald.com/news/nation-world/ world/americas/cuba/article219074565.html (accessed 21 April 2021).

OFAC (2011) "Section 515.204 importation of and dealings in certain merchandise". Available at: https://www.govinfo.gov/content/pkg/CFR-2011-title31-vol3/pdf/CFR2011-title31-vol3-sec515-204.pdf (accessed 22 April 2021).

OFAC (2016) "Section 515.547 certain transactions related to medical research and Cuban-origin pharmaceuticals: research samples”. Available at: https://www.law.cornell.edu/cfr/text/31/515.547 (accessed 28 October 2021).

OFAC (2017) "Restrictions on direct financial transactions with certain entities and subentities”. Available at: https:/www.treasury.gov/resource-center/sanctions/programs/ documents/cuba_faqs_new.pdf (accessed 21 April 2021).

Newsweek (1978) "Cubans in Africa: Moscow tests Carter" (13 March): 37.

Pergament, Alan (2020) “Roswell Park's alliance with Cuba gets the 'wow' treatment from PBS' Nova”. Available at: https://buffalonews.com/opinion/columnists/roswellparks-alliance-with-cuba-gets-the-wow-treatment-from-pbs-nova/article_5f70faea6d18-5a7b-bbfa-8b43ac4dd158.html (accessed 20 April 2021).

Rojo Pérez, Nereida, et al. (2018) "Science and tecnological innovation in health in Cuba: Results in selected problems", Pan American Journal of Public Health, 42: 1-11.

Spetalnick, Matt (2021) "Exclusive: Biden in no rush to lift Venezuela sanctions, seeks 'serious steps' by Maduro". Available at: https://www. reuters.com/article/us-venezuela-usa-exclusive/exclusive-biden-in-no-rush-to-lift-venezuela-sanctions-seeks-serious-steps-by-maduro-idUSKCN2AS0FB (accessed 20 April 2021).

Weissenstein, Michael (2017) “Artisanal marabu charcoal to become 1st Cuban export to US”. Miami Herald. Available at: https://www.miamiherald.com/news/nation-world/ world/americas/cuba/article124763374 (Accessed 18 April 2021). 